\title{
EFFECT OF THE PRESENCE OF INITIAL ETHANOL ON ETHANOL PRODUCTION IN SUGAR CANE JUICE FERMENTED BY ZYMOMONAS MOBILIS
}

\author{
Marcia Sadae Tano*; João Batista Buzato \\ Departamento de Bioquímica, Universidade Estadual de Londrina, Londrina, PR, Brasil.
}

Submitted: August 21, 2001; Returned to Authors: November 22, 2001; Approved: August 28, 2003

\begin{abstract}
Ethanol production in sugar cane juice in high initial sugar concentration, fermented by Z. mobilis in the presence and absence of ethanol, was evaluated. Ethanol production was low in both media. The presence of initial ethanol in the sugar cane juice reduced ethanol production by $48.8 \%$, biomass production by $25.0 \%$ and the total sugar consumption by $28.3 \%$. The presence of initial ethanol in the medium did not affect significantly levan production and biomass yield coefficient ( $\mathrm{g}$ biomass/g sugar consumed).
\end{abstract}

Key words: ethanol, sugar cane, Z. mobilis, fermentation.

\section{INTRODUCTION}

In Brazil, ethanol produced by sugar cane juice fermentation is used as fuel. The sucrose-based ethanol industry has traditionally utilised sugar cane juice due to its high sucrose content and wide cultivation. The utilisation of high initial sugar concentration in the wort is advantageous for the industry. However, ethanol produced during carbohydrate metabolism has been considered a major factor of cell stress, limiting growth, metabolic activity and ethanol production (7).

The bacterium Zymomonas mobilis has been the focus of considerable research in recent years due to its great potential for use in large-scale ethanol production $(4,5,16)$. Ethanol and carbon dioxide are the main fermentation products of glucose, fructose or sucrose by Entner-Doudoroff metabolic pathway of Z. mobilis (10).

Lopez et al. (13) have reported that the metabolic activity of $Z$. mobilis depends on the strain and on the carbon sources, while Diez and Yokoya (4) have mentioned that several by-products may be produced during fermentation of sucrose by Z. mobilis, such as: phenol, lactic acid, higher alcohols, acetaldehyde, methanol and levan. Levan is a polysaccharide of fructose produced when sucrose is fermented by Z. mobilis $(1,2)$.

Literature data are not uniform with respect to the use of $Z$. mobilis in fermentation. Doelle and Greenfield (5) reported that the high initial sugar concentration in the medium resulted in long fermentation time to achieve high conversion efficiency. Favela Torres and Baratti (6) reported correlation between high substrate concentration and growth of Z. mobilis and found that the fermentation ended at $\mathrm{pH}$ 3.5. On the other hand, the use of high initial sugar concentration was described as a cause of incomplete utilisation of sugar $(9,23)$. Nevertheless, there has been only few publications on sugar cane juice fermentation by Z. mobilis $(5,8,17,23)$.

The objective of this work was to examine the effect of the presence of initial ethanol on production of ethanol in sugar cane juice fermented by Z. mobilis. Levan and biomass production were also examined.

\section{MATERIALS AND METHODS}

Microorganism and culture conditions: Z. mobilis ATCC 31821 was used. It was maintained by monthly transfer to the following medium $(\mathrm{g} / \mathrm{L})$ : sucrose, 50.0; yeast extract, 5.0; $\mathrm{KH}_{2} \mathrm{PO}_{4}, 1.0 ;\left(\mathrm{NH}_{4}\right)_{2} \mathrm{SO}_{4}, 1.0 ; \mathrm{MgSO}_{4}, 0.50$.

Fermentation medium composition $(\mathrm{g} / \mathrm{L})$ : sugar cane juice with initial Total Reducing Sugar (initial TRS) adjusted to 151.9; yeast extract (Difco), 5.0; $\mathrm{KH}_{2} \mathrm{PO}_{4}, 1.0 ; \mathrm{MgSO}_{4}, 0.50 ;\left(\mathrm{NH}_{4}\right)_{2} \mathrm{SO}_{4}$, 1.0. The medium ( $100 \mathrm{~mL}$ for each $250 \mathrm{~mL}$ Erlenmeyer flask) was sterilised by autoclaving $\left(121^{\circ} \mathrm{C} / 5 \mathrm{~min}\right)$ and after cooling, $2.5 \%$

*Corresponding author. Mailing address: Departamento de Bioquímica, Universidade Estadual de Londrina. Caixa Postal 6001. 86051-900, Londrina, PR, Brasil. Tel.: (+5543) 371-4270. Fax: (+5543) 371-4216. E-mail: buzato@uel.br 
(v/v) of ethanol GR (Merck) was aseptically added (named Medium I). Control medium (named Medium II) had no added ethanol. Initial pH was 5.4.

Inoculum: biomass, obtained in Medium II at $28^{\circ} \mathrm{C}$ without agitation for $18 \mathrm{~h}$, was centrifuged. The cells were resuspended in Medium II and added for culture flasks with Medium I and Medium II to achieve a concentration of $0.2 \mathrm{mg}$ of cells $/ \mathrm{mL}$.

Fermentation procedure: the experiment was conducted in triplicates at $28^{\circ} \mathrm{C}$ (using Media I and II) in a gyratory bath shaker operating at a speed of $180 \mathrm{rpm}$ during $48 \mathrm{~h}$. The experiment had control flasks, with and without added initial ethanol (without inoculum).

Biomass was measured spectrophometically using Metrolab M 1700 spectrophotometer (Bernal, Argentina). A conversion factor $\left(1.0 \mathrm{OD}_{605 \mathrm{~nm}}=0.275 \mathrm{mg}\right.$ dry $\mathrm{wt} / \mathrm{mL}$ ) was obtained from a standard curve relating absorbance to dry weight, according to Peres and Laluce (19). Determination of levan was as described by Dawes et al. (3). Levan was separated by ethanol precipitation, centrifuged $(4.700 \mathrm{x} \mathrm{g} /$ $15 \mathrm{~min}$ ) and hydrolysed in $1.0 \mathrm{M} \mathrm{HCl}$ at $65^{\circ} \mathrm{C}$ for $30 \mathrm{~min}$. The hydrolyzed solution was neutralized with $2.0 \mathrm{M} \mathrm{NaOH}$ and estimated as Reducing Sugar (RS).

TRS and RS were assayed by the Somogyi method (21) at $540 \mathrm{~nm}$. Samples for TRS determination were obtained by hydrolysis in $1.0 \mathrm{M} \mathrm{HCl}$, at $65^{\circ} \mathrm{C}$ for $30 \mathrm{~min}$, and neutralized with 2.0 $\mathrm{M} \mathrm{NaOH}$, and estimated as RS.

Ethanol analysis was performed using a CG-17A Shimadzu gas chromatograph(Kioto, Japan) with Dbwax column $(30 \mathrm{~cm} /$ $0.25 \mathrm{~cm}$ ). The oven temperature was maintained at $60^{\circ} \mathrm{C}$ with injector and detector temperatures at $150^{\circ} \mathrm{C}$ and $250^{\circ} \mathrm{C}$, respectively. Ethanol was extracted with isopropanol.

\section{RESULTS AND DISCUSSION}

Table 1 shows results for Ethanol [E], Levan [L] and Biomass [B] production, obtained in sugar cane juice medium fermented by $Z$. mobilis.

In the present study, the final $\mathrm{pH}$ values were 3.81 and 3.76 for Media II and I, respectively, and the fermentation ceased at $48 \mathrm{~h}$ with high residual sugar concentration (residual TRS), which indicates incomplete fermentation (23).

The total sugar consumption in Medium II was $69.0 \mathrm{~g} / \mathrm{L}$ and $49.5 \mathrm{~g} / \mathrm{L}$ in Medium I. The sugar consumed in Medium I was 28.3\% lower than in Medium II. In this study, the sugar consumption (TRS consumption) in the fermentation for ethanol, levan and biomass production was calculated as a percentage of initial TRS, and the value for Media II and I were $45.4 \%$ and $32.6 \%$, respectively. Moreau et al. (14), using 3.0\% of initial ethanol in the glucose medium, obtained reduction of $60-65 \%$ in glucose consumption. However, they have utilised a medium with low initial glucose concentration.
Table 1. Parameters of sugar cane juice fermented by Z. mobilis ATCC31821 (28 ${ }^{\circ} \mathrm{C} / 180 \mathrm{rpm} / 48$ hours) in Medium I (with $2.5 \%$ (v/v) of initial ethanol) and in Medium II (without initial ethanol = Control medium).

\begin{tabular}{lcccccc}
\hline \multicolumn{1}{c}{ Parameters } & & $\begin{array}{c}\text { Medium } \\
\mathrm{I}^{*}\end{array}$ & $\begin{array}{c}\text { SD } \\
\text { (I) }\end{array}$ & $\begin{array}{c}\text { Mediu } \\
\text { m II* }\end{array}$ & $\begin{array}{c}\text { SD } \\
\text { (II) }\end{array}$ & $\begin{array}{c}\text { Ratio* } \\
\text { (I)/(II) }\end{array}$ \\
\hline Initial TRS & $(\mathrm{g} / \mathrm{L})$ & 151.9 & - & 151.9 & - & 1.00 \\
Residual TRS & $(\mathrm{g} / \mathrm{L})$ & 102.5 & - & 83.0 & - & 1.23 \\
TRS consumption & $(\mathrm{g} / \mathrm{L})$ & 49.5 & \pm 0.14 & 69.0 & \pm 0.15 & 0.72 \\
Initial RS & $(\mathrm{g} / \mathrm{L})$ & 15.0 & - & 15.0 & - & 1.00 \\
Residual RS & $(\mathrm{g} / \mathrm{L})$ & 55.1 & \pm 0.16 & 50.3 & \pm 0.06 & 1.09 \\
{$[\mathrm{~B}]$} & $(\mathrm{g} / \mathrm{L})$ & 1.75 & \pm 0.03 & 2.34 & \pm 0.02 & 0.75 \\
{$[\mathrm{E}]$} & $(\mathrm{g} / \mathrm{L})$ & 14.1 & \pm 0.09 & 29.0 & \pm 0.09 & 0.49 \\
{$[\mathrm{~L}]$} & $(\mathrm{g} / \mathrm{L})$ & 1.56 & \pm 0.02 & 1.72 & \pm 0.02 & 0.91 \\
Ye/s & $(\mathrm{g} / \mathrm{L})$ & 0.285 & - & 0.420 & - & 0.68 \\
Yb/s & $(\mathrm{g} / \mathrm{L})$ & 0.035 & - & 0.034 & - & 1.03 \\
Conv. Effic. & $(\mathrm{g} / \mathrm{L})$ & 55.9 & - & 82.3 & - & 0.68 \\
pH & $(\mathrm{g} / \mathrm{L})$ & 3.76 & - & 3.81 & - & 0.99 \\
\hline
\end{tabular}

*Values are means of triplicates; SD=Standard Deviation; $[\mathrm{B}]=$ concentration of biomass; $[\mathrm{E}]=$ concentration of ethanol; $[\mathrm{L}]=$ concentration of levan; Ye/s $=\mathrm{g}[\mathrm{E}] / \mathrm{g}$ consumed sugar; $\mathrm{Yb} / \mathrm{s}=\mathrm{g}[\mathrm{B}] / \mathrm{g}$ consumed sugar; Conv. Effic.$=100 .[\mathrm{E}] / 0.511 . \mathrm{TRS}$ consumption.

Ethanol conversion efficiency values of the total sugar (Conv. Effic. $=100 .[\mathrm{E}] / 0.511$.TRSconsumption) were $82.3 \%$ and $55.9 \%$ for Media II and I, respectively. The addition of ethanol to the medium caused a slump of $25.0 \%$ in the conversion efficiency. The ethanol conversion efficiency obtained in Medium II is comparable to that obtained by Diez and Yokoya (4).

Ethanol production was unsatisfactory: in Medium II, it achieved 29.0 g/L, and the ethanol yield coefficient $(\mathrm{Ye} / \mathrm{s}=\mathrm{g}[\mathrm{E}] / \mathrm{g}$ consumed sugar) was 0.420 . In Medium I, the ethanol production was $14.1 \mathrm{~g} / \mathrm{L}$ (final - initial ethanol), and the ethanol yield coefficient was 0.285 . In Medium I, there was $48.8 \%$ reduction in ethanol production when compared to Medium II. These results are in agreement with those reported in several other studies $(8,9,23)$.

Our result is also in agreement with Park and Baratti (17), who showed that the poor performance of Z. mobilis for ethanol production was due to the substrate (sugar cane juice and molasses). In addition, several mineral compounds present in sugar cane juice and molasses are known to be inhibitors of fermentation by Z. mobilis $(12,13)$. However, the physiological effects of those mineral compounds on the growth are scarcely described in the literature.

Biomass production in Media II and I were, respectively $2.34 \mathrm{~g} / \mathrm{L}$ and $1.75 \mathrm{~g} / \mathrm{L}$. A reduction of $25.0 \%$ in biomass value was found in Medium I when compared to Medium II. However, these values did not interfere in ethanol production because conversion of sugar consumption into biomass was $3.5 \%$ in Medium II and $3.4 \%$ in Medium I. The biomass yield coefficient 
$(\mathrm{Yb} / \mathrm{s}=\mathrm{g}[\mathrm{B}] / \mathrm{g}$ consumed sugar) obtained in the Medium II was 0.035 and 0.034 in Medium I.

Several authors have reported levan production with reduction on ethanol production $(10,17)$. Levan production in Media II and I was $1.72 \mathrm{~g} / \mathrm{L}$ and $1.56 \mathrm{~g} / \mathrm{L}$, respectively. These values are very similar and low enough to indicate that the addition of initial ethanol had no influence in production of ethanol. These results are in agreement with Crittenden and Doelle (2), who demonstrated that levansucrase, the key-enzyme in levan production, is not inhibited by ethanol.

Ethanol, levan and biomass production was responsible for 88.2\% of total substrate consumption in Medium II and 62.6\% in Medium I. This suggests that substrate was also used for formation of by-products such as methanol, acetaldehyde, phenol, lactic acid and higher alcohols. These by-products have been considered inhibitors of fermentation $(9,11,12,15,22)$. In sugar cane juice fermentation by Z. mobilis, carried out at a higher initial sugar concentration, the inhibition on ethanol production may be caused by both ethanol and by-products.

The results presented here showed that presence of $2.5 \%$ $(\mathrm{v} / \mathrm{v})$ initial ethanol in the medium diminishes biomass production, substrate consumption and ethanol production, yield and conversion efficiency, when sugar cane juice is fermented by Z. mobilis. However, the presence of initial ethanol did not interfere in levan production and biomass yield. Despite the presence of high initial sucrose and directly fermentable monosaccharides in the medium, they did not favour ethanol, levan or biomass production.

\section{RESUMO}

\section{Efeito da presença de etanol inicial na produção de etanol em caldo de cana-de-açúcar fermentado por Zymomonas mobilis}

Foi avaliada a produção de etanol em caldo de cana-deaçúcar com alta concentração de açúcar inicial, fermentado por Z. mobilis, na presença e na ausência de etanol inicial. A produção de etanol nos dois meios foi baixa. A presença de etanol inicial no caldo de cana-de-açúcar causou uma redução de $48,8 \%$ na produção de etanol, de $25 \%$ na produção de biomassa e de $28,3 \%$ no consumo de açúcar total. A presença de etanol inicial ao meio não teve efeito significante para a produção de levana e no coeficiente de produtividade em biomassa ( $\mathrm{g}$ biomassa/g açúcar consumido).

Palavras-chave: etanol, açúcar da cana, Z. mobilis, fermentação.

\section{REFERENCES}

1. Ananthalakshmy, V.K.; Gunasekaran, P. Optimization of levan production by Zymomonas mobilis. Braz. Arch. Biol. Technol., 42(3):292-297, 1999.
2. Crittenden, R.G.; Doelle, H.W. Identification and characterisation of the extracellular sucrases of Zymomonas mobilis UQM 2716 (ATCC 39676). Appl. Microbiol. Biotechnol., 41:302-308, 1994.

3. Dawes, E.A.; Ribbons, D.W.; Rees, D.A. Sucrose utilization by Zymomonas mobilis: formation of a levan. Biochem. J., 98:804-812, 1966.

4. Diez, J.C.; Yokoya, F. Effect of temperature and $\mathrm{pH}$ on ethanol and levan production during sucrose fermentation by Zymomonas mobilis. Arq. Biol. Tecnol., 39(1):129-137, 1996.

5. Doelle, H.W.; Greenfield, P.F. The production of ethanol from sucrose using Zymomonas mobilis.Appl. Microbiol. Biotecnol., 22:405-410, 1985.

6. Favela Torres, E.; Baratti, J. The effect of $\mathrm{pH}$, temperature and sucrose concentration on high productivity continuous ethanol fermentation using Zymomonas mobilis. Appl. Microbiol. Biotechnol., 27:121-128, 1987.

7. Hallsworth, J.E. Ethanol-induced water stress in yeast. J. Ferment. Bioeng., 85(2):125-137, 1998.

8. Huertaz-Díaz, H.; Cacho, C.L.; Bernard, L. Fermentation of sugarcane juice and blackstrap molasses by Zymomonas mobilis. J. Agric. Univ. P.R., 75(1):43-50, 1991.

9. Joachimsthal, E.; Haggett, K.D.; Jang, J-H.; Rogers, P.L. A mutant of Zymomonas mobilis ZM4 capable of ethanol production from glucose in the presence of high acetate concentrations. Biotechnol. Lett., 20(2):137-142, 1998.

10. Kannan, T.R.; Sangiliyandi, G.; Gunasekaran, P. Influence of intra- and extracellular sucarases of Zymomonas mobilis on the ethanol production and by-product formation. Biotechnol. Lett., 19(7):661-664, 1997.

11. Lawford, H.G.; Rousseau, J.D. Corn steep liquor as a cost-effective nutrition adjunct in high-performance Zymomonas ethanol fermentations. Appl. Biochem. Biotechnol., 63-65:287-304, 1997.

12. Lawford, H.G.; Rousseau, J.D. Conditions that promote production of lactic acid by Zymomonas mobilis in batch and continuous culture. Appl Biochem. Biotechnol., 70-72:173-185, 1998.

13. López, J.A.; Calazans, G.M.T.; Silveira, M.M.; Jonas, R.; Lopes, C.E. The effect of carbon sources on the settling behaviour of flocculent strains of Zymomonas mobilis.Bioseparation., 6:229-232, 1996.

14. Moreau, R.A.; Powell, M.J.; Fett, W.F.; Whitaker, B.D. The effect of ethanol and oxygen on the growth of Zymomonas mobilis and the levels of hopanoids and other membrane lipidis. Cur. Microbiol., 35:124-128, 1997.

15. Nidetzky, B.; Fürlinger, M.; Gollhofer, D.; Scopes, R.K.; Haltrich, D.; Kulbe, K.D. Improved operational stability of cell-free glucosefructose oxidoreductase from Zymomonas mobilis for the efficient synthesis of sorbitol and gluconic acid in a continuous ultrafiltration membrane reactor. Biotechnol. Bioengin., 53:623-629, 1997.

16. Palha, M.A.P.F.; Lopes, C.E.; Pereira Jr., N. Ethanol stimulates the flocculation of Zymomonas mobilis. Biotechnol. Lett., 19(6):499501, 1997.

17. Park, S.C.; Baratti, J. Effects of potassium chloride on ethanol production by an osmotolerant mutant of Zymomonas mobilis. Appl. Microbiol. Biotechnol., 38:542-549, 1993.

18. Parker, C.; Peekhaus, N.; Zhang, X.; Conway, T. Kinetics of sugar transport and phosphorylation influence glucose and fructose cometabolism by Zymomonas mobilis. Appl. Environ. Microbiol., 63(9):3519-3525, 1997.

19. Peres, M.F.S.; Laluce, C. Ethanol tolerance of thermotolerant yeasts cultivated on mixtures of sucrose and ethanol. J. Ferment. Bioengin.;85(4): 388-397, 1998.

20. Rogers, P.L.; Lee, K.J.; Skotnicki, M.L.; Tribe, D.E. Ethanol production by Zymomonas mobilis. Adv. Biochem. Eng., 23:37-84, 1982.

21. Somogyi, M.A. A new reagent for the determination of sugar. Biol. Chem., 160:61-68, 1945.

22. Stanley, G.A.; Hobley, T.J.; Pamment, N.B. Effect of acetaldehyde on Saccharomyces cerevisiae and Zymomonas mobilis subjected to enviromnental shocks. Biotech. Bioeng., 53:71-78, 1997.

23. Tano, M.S.; Buzato, J.B.; Celligoi, M.A.P.C. Sugar cane juice fermentation by Zymomonas mobilis CP4 subjected to inhibition by ethanol and high initial concentration of substrate. Braz. Arch. Biol. Technol., 43(4):425-430, 2000. 